\title{
霧島連山・新燃岳の火山災害による 事業所被災と自治体対応
}

\author{
宇野 宏司 $1 \cdot$ 中野 晋 $2 \cdot$ 粕淵 義郎3 \\ ${ }^{1}$ 正会員＼cjkstart神戶市立工業高専准教授＼cjkstart都市工学科（７６51-2194 兵庫県神戶市西区学園東町8-3） \\ E-mail:uno@kobe-kosen.ac.jp \\ 2正会員 德島大学教授 環境防災研究センター ( ₹ 770-8506 徳島県德島市南常三島2-1) \\ E-mail:nakano@ce.tokushima-u.ac.jp \\ 3正会員 德島大学助教 環境防災研究センター ( T 770-8506 德島県德島市南常三島2-1) \\ E-mail:kasubuchi@hyd.ce.tokushima-u.ac.jp
}

\begin{abstract}
南九州・霧島連山の新燃岳 (標高 $1,421 \mathrm{~m})$ では, 平成23年1月に52年ぶりの爆発的噴火が起き，宮崎・ 鹿児島両県で降灰や噴石による被害が報告された . 先行きの見えない噴火活動が住民の生活や企業活動に 与える影響は大きく，また長期化することが懸念される．本研究では，各種公表資料，自治体や企業での ヒアリング調査結果をもとに，本災害による事業所や自治体の被災状況と当時の対応，今後の対策につい て整理し, 長期化する恐れのある火山災害時における企業の事業継続に必要な観点について整理した .

突発的な今回の火山噴火は, 当該地域の火山災害に対する防災体制の不備な点を明らかにした．今後， 火山災害の影響を受けない地域をも含めたより広域的な連携関係を構筑しておくことや，風評被害を防ぐ ための復旧過程での積極的な報道の利用等が重要であると考えられる．
\end{abstract}

Key Words : Shinmoedake, explosive eruption, volcanic ash, ballistic projectile, BCP

\section{1. はじめに}

新燃岳（標高 $1,421 \mathrm{~m})$ は，南九州・霧島連山の一部を なし, 同連山の最高峰である韓国岳 $(1,700 \mathrm{~m})$ と天孫降 臨神話て知られる高千穂峰 $(1,574 \mathrm{~m})$ の中間に位置する 比較的新しい活火山である .

新燃岳では平成23年1月以来，火山活動が活発化し， 周辺地域で人的・物的被害力報告されている.特に広 範囲にわたる降灰が住民生活や企業活動に与える影響は 大きく，長期化することか懸念されている．

本研究では, 自治体の公表資料, 新聞等の報道記事, 図-1の調査地域において実施した自治体や企業でのヒア リンク調査の結果をもとに，本災害による事業所や自治 体の被災状況と当時の対応を整理し，長期化する恐れの ある火山災害時の企業及び事業継続に必要な観点につい て整理した。

\section{2. 新燃岳火山噴火災害の概要と行政対応}

（1）噴火経緯と被害の概要

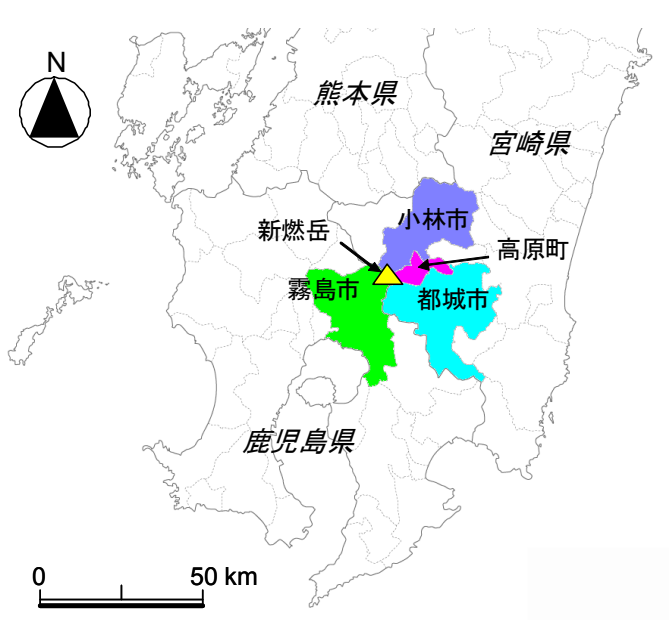

図-1 調査地域

表-1に，平成23年1月から3月にかけての新燃岳の噴火 経緯と行政等による主な対応を示す．本表は政府や県の 公表資料1,2)のほか, 新聞記事等を参考に整理したもの である.新燃岳では平成23年1月26日に，1,500mに達す る噴煙をともなう噴火を機に活動が活発となり，同年 1月27日には1回目の爆発的噴火を引き起こした .この爆 発は52年ぶらのもので, マグマ噴火としては江戶時代の 
表-1＼cjkstart新燃岳の噴火経緯と行政等の主な対応

\begin{tabular}{|c|c|c|c|}
\hline \multicolumn{2}{|l|}{ 日時 } & \multirow[b]{2}{*}{ 小規模な噴火が発生 } & \multirow[t]{2}{*}{ 行政等の主な対応 } \\
\hline 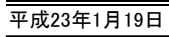 & 13時30分 & & \\
\hline & 7 時31分 & ごく小規模な噴火が発生 & 【都城市】17時00分 予備配備開始 【露島市】18時30分 災害警戒本部設置 \\
\hline 1月26日 & 15時40分 & 噴煙が $1,500 \mathrm{ml}$ に達する噴火が発生しし，その後も断続的に噴火 & 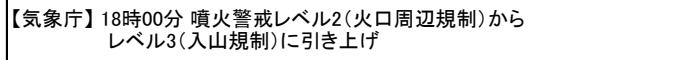 \\
\hline & 1時ごろ & 空振や鳴動の報告 & 【都城市】13時30分 新然岳火山防災連絡会 \\
\hline 1月27日 & & & [鹿児島県】17時30分 災害警戒本部設置 \\
\hline & 15時41分 & 1回目の爆発的噴火(189年ぶり)，噴煙は2,500ml二達する & 【国交省ほか】17時00分 霧島火山防災連絡会 \\
\hline 1月28日 & 12時47分 & 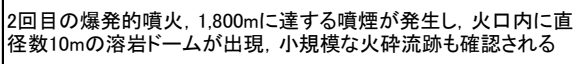 & 【都城市】9時 00 分災害対策本部設置 \\
\hline 1月29日 & & & 11時15分 国土交通大臣現地視察，15時30分 防災担当·環境大臣現地視察 \\
\hline 1月30日 & 13晆57分 & 3回目の懪登的喷火 & 【都城市】23時45分 災害対策本部会議 \\
\hline T月30口 & 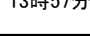 & 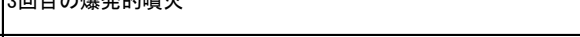 & 【高原町】23時50分 避難勧告発表 (513世带, 1,158人) \\
\hline 1月31日 & & 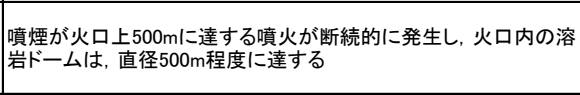 & 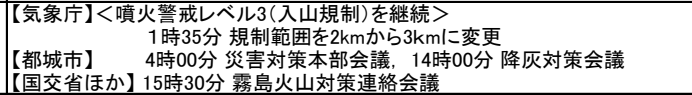 \\
\hline 2月1日 & $\begin{aligned} 7 \text { 時 } 54 \text { 分 } \\
23 \text { 時19分 }\end{aligned}$ & $\begin{array}{l}\text { 44回目の爆発的噴火. 噴煙が火口上2,000mに達する } \\
5 \text { 5回目の爆発的噴火 }\end{array}$ & 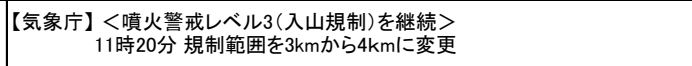 \\
\hline 2月2日 & $\begin{array}{r}5 \text { 時25分 } \\
10 \text { 時47分 } \\
15 \text { 時53分 }\end{array}$ & $\begin{array}{l}\text { 6回目の爆発的噴火 } \\
7 \text { 回目の爆発的噴火 } \\
\text { 8回目の爆発的噴火 } \\
\end{array}$ & \\
\hline 2月3日 & 8時09分 & 9回目の爆発的噴火 & $\begin{array}{l}\text { [都城市】14時00分 土石流·泥流警戒区域協議 } \\
\text { [省ほか】15時00分 霧島火山防災連絡会 }\end{array}$ \\
\hline 2月4日 & & & 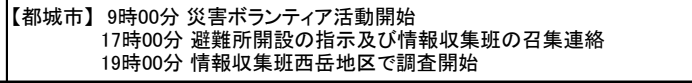 \\
\hline 2月5日 & & & 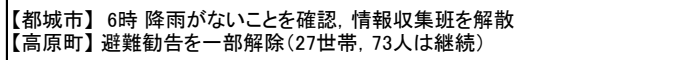 \\
\hline 2月7日 & & & 政府支援チームが宮崎県を訪問 \\
\hline 2月8日 & & & 【都城市】15時30分 災害対策本部会議 \\
\hline 2月10日 & & & 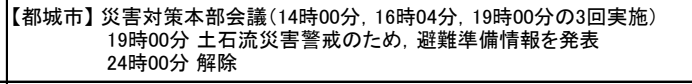 \\
\hline 2月11日 & 11時36分 & 10回目の爆発的噴火 & 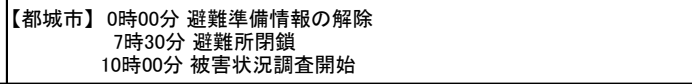 \\
\hline 2月13日 & & & $\begin{array}{l}\text { 【都城市】17時00分 災害対策本部会議 } \\
\text { 17時23分 土石流災嗐警戒のた避難準備情報を発表 }\end{array}$ \\
\hline 2月14日 & 5時07分 & 11回目の爆発的噴火 & 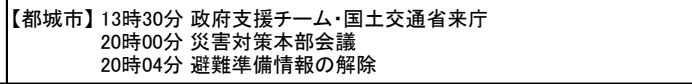 \\
\hline 2月15日 & & & 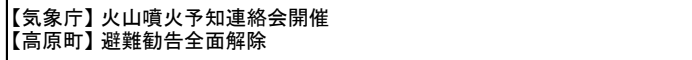 \\
\hline 2月16日 & & & 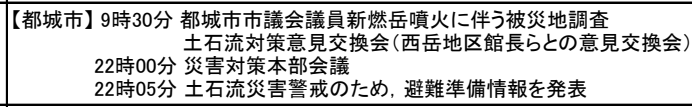 \\
\hline 2月17日 & & & 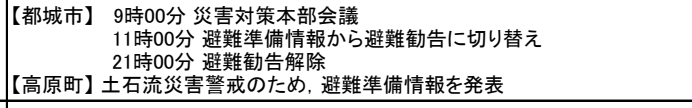 \\
\hline 2月18日 & 18時16分 & 12回目の爆発的噴火 & 【都城市】9時30分 被害状況調査開始 \\
\hline 2月22日 & & & 霧島火山防災連絡会コアメンバー会議(第1回)開催 \\
\hline 2月23日 & & & 【都城市】13時30分, 16時30分 災害対策本部会議 \\
\hline 2月25日 & & & 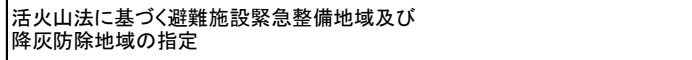 \\
\hline 2月27日 & & & 【都城市】15時00分 災害対策本部会議 \\
\hline 2月28日 & & & 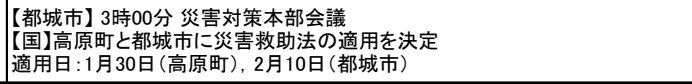 \\
\hline 3月1日 & 19時23分 & 13回目の爆発的噴火 & \\
\hline 3月10日 & & & 霧島火山防災連絡会コアメンバー会議(第5回)開催 \\
\hline 3月11日 & & & 政府支援チ一八撤収(連絡調整班は残置) \\
\hline
\end{tabular}

「霧島火山防災連絡会」は、宮崎河川国道事務所長を事務局長として、霧島周辺の自治体をはじめ、九州地方整備局、国土地理院、気象庁、

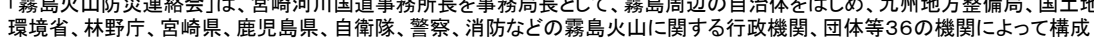

「享保噴火」以来，実に約300年ぶりのイベントであっ た . 以後, 同年3月までに13回もの爆発的噴火力確認さ れ，現在も噴火警戒レベル3の入山規制が布かれている . 一連の噴火によって山麓の住民の一部は一時避難を余儀 なくされた . また , 周辺への降灰 (写真-1) は , 住民生 活や農業 , 商工業にも大きな影響を与えた . 表-2に一連
の噴火活動による人的・物的被害状況を示す．宮崎，鹿 児島両県とも，死者・行方不明者は0で，負傷者の多く は降灰除去作業中の事故もしくは空振で飛散したガラス 破片による怪我がほとんどであり，噴石 (写真-2参照) 等の火山噴出物か直撃するような事態は起きていない． また, 物的被害については, 霧島市 (鹿児島県) で空振 
表-2 被害状況 (人的・物的被害等)

\begin{tabular}{|c|c|c|c|c|c|c|}
\hline \multirow{2}{*}{\multicolumn{3}{|c|}{ 項目 }} & \multicolumn{3}{|c|}{ 宮崎県 } & \multirow{2}{*}{$\begin{array}{c}\text { 鹿児島県 } \\
\text { 霧島市 }\end{array}$} \\
\hline & & & 都城市 & 高原町 & 小林市 & \\
\hline \multirow{5}{*}{ 人的被害 } & \multicolumn{2}{|c|}{ 死者 } & 0 & 0 & 0 & 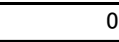 \\
\hline & \multicolumn{2}{|c|}{ 行方不明者 } & 0 & 0 & 0 & 0 \\
\hline & \multirow{3}{*}{ 負傷者 } & 重傷 & 13 & 2 & 0 & 0 \\
\hline & & 軽傷 & 20 & 1 & 0 & 1 \\
\hline & & 計 & 36 & 3 & 0 & 0 \\
\hline \multirow{2}{*}{ 住家被害 } & \multicolumn{2}{|c|}{ 損壊 (全壊·半壊·一部損壊 } & 0 & 0 & 0 & 0 \\
\hline & \multicolumn{2}{|c|}{ 浸水 (床上·床下) } & 0 & 0 & 0 & 0 \\
\hline \multirow{2}{*}{ その他 } & \multicolumn{2}{|c|}{ 空振被害 ${ }^{* 1}$} & 2 & 0 & 0 & 215 \\
\hline & \multicolumn{2}{|c|}{ 噴石被害 *2 } & 2 & 23 & 696 & 0 \\
\hline
\end{tabular}

" 空振によるドア, 自動車ガラスの破損

*2 噴石による自動車ガラス, 太陽光パネル, 屋根(波板)の破損

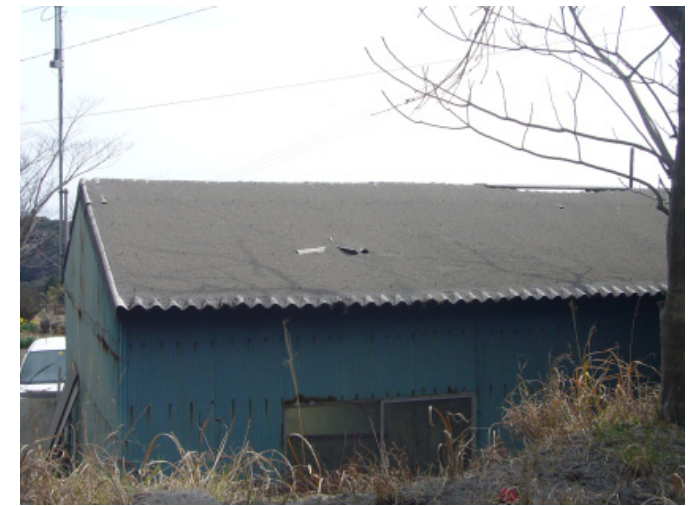

写真-1 トタン屋根に降り積もつたままの火山灰 (西岳地区, 平成23年3月27日撮影)

表-3 被害状況 (農林水産業)

\begin{tabular}{|c|c|c|c|c|}
\hline & \multirow{2}{*}{ 項目 } & \multicolumn{2}{|c|}{ 県 } & \multirow{2}{*}{ 内容 } \\
\hline & & 宮崎県 & 鹿児島県 & \\
\hline \multirow[t]{2}{*}{ 農業 } & 農作物被害 & $\begin{array}{c}12,554 \text { ha } \\
\text { (591,186千円) }\end{array}$ & $\begin{array}{c}147 \mathrm{ha} \\
(21,137 千 円)\end{array}$ & 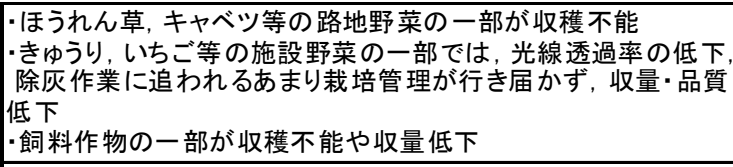 \\
\hline & 農地·農 業用施設 & $\begin{array}{c}665 \text { 箇所 } \\
(595,000 \text { 千円 })\end{array}$ & - & $\begin{array}{l}-\cdot \text { 灰の重みや空振によりビニルハウスが破損 } \\
\cdot \text { 牛舎や倉庫が, 噴石や灰の重みにより破·倒壊 } \\
\cdot \text { ·降灰により, 農地, 農業用施設, 農道, 水路等が埋没し, } \\
\text { 営農に支障をきたすす }\end{array}$ \\
\hline \multirow[t]{2}{*}{ 林業 } & 特用林産 & $\begin{array}{c}37.14 \mathrm{ha} \\
(14,625 \text { 千円 })\end{array}$ & $\begin{array}{c}\text { 3箇所 } \\
\text { (100千円) }\end{array}$ & $\begin{array}{l}\text {-降灰により, 原木しいたけの一部が出荷停歨 } \\
\text {-降灰により, しいたけ生産用ビニルハウスが倒壊 }\end{array}$ \\
\hline & 森林施業 & - & - & -降灰により間伐，伐採作業に支障をきたす \\
\hline 水産業 & 養殖業 & $\begin{array}{c}20 \text { 万尾 } \\
(1,300 千 円)\end{array}$ & - & -降灰により一部の養殖場でヤマメ稚魚がへい死 \\
\hline
\end{tabular}

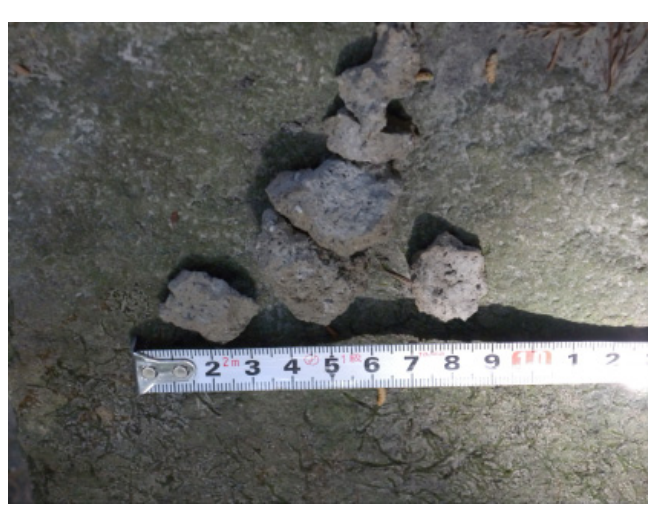

写真-2 霧島東神社で見られた噴石 (平成23年3月27日撮影)

によるドア，自動車ガラスの破損，小林市 (宮崎県) で 噴石による自動車ガラス，太陽光パネル，屋根（波板） の破損が目立った .

表-3に宮崎，鹿児島両県による農林水産業の被害状況 を示す . 各産業とも降灰による被害がほとんどで, 噴火 時に風下に置かれることの多かった宮崎県側での被害が 深刻であった . とりわけ水分を含み固まった灰の除去は 困難を極め，降雨時には泥流や土石流の危険性を高める など，風水害のような一過性の自然災害とは異なる終わ りの見えない不安か地域経済に重くのしかかる結果とな
つた。

霧島温泉郷 (霧島市) では，噴火警戒レベルを2（火 口周辺規制) から3 (入山規制) に引き上げられたこと を機に，危険区域内の2つの宿泊施設が営業の自肃を余 儀なくされたほか , ホテル・旅館等の宿泊・宴会のキャ ンセルや観光地・施設の閉鎖が相次いだ .

電気，水道，ガス，通信等のライフラインや鉄道，道 路等のインフラ施設については，いずれも降灰に見舞わ れたものの，損壊等の被害は出ていない.ただし，1回 目の爆発的噴火では，鉄道が一時，運転を見合わせたほ か，国・県道では一部区間が通行止めとなった．また， 宮崎空港の滑走路か33時間半にわたって閉鎖されるなど の影響が出た .

(2) 行政等の対応

ここでは都城市役所，小林市役所，高原町役場の担当 者からのヒアリング (平成23年3月26日実施) や自治体 の発表資料をもとに当時の行政の対応を整理する．なお， これら行政の主な対応の時系列は表-1を参照されたい．

a) 都城市の対応 ${ }^{3)}$

都城市では，新燃岳の噴火活動が活発化したのを受け て，平成23年1月30日に災害対策本部会議を開催した 。 県の危機管理課より警戒レベル3から4 (避難準備) への 
引き上げ可能性の示唆を受け, 新燃岳火口から $10 \mathrm{~km}$ 圏 内 564 世帯 1,232 人に対し, 避難隼備情報の開示準備をし たが, 早急に大規模噴火は発生しないとの判断から，発 表には至らなかった .

以後, 2月末までに14回もの災害対策本部会議か開催 され，7回にわたり土石流に対する避難の検討が行われ た.このうち，実際に避難隼備情報か発表されたのは， 2月10日19時，2月13日17時25分と2月16日22時5分の3回で あつた .なお，2月16日の避難準備情報発表後，累加雨 量が規定値に達したため，2月17日11時に避難勧告が出 され，95世帯145人が近くの小学校等に避難した（同日 21時に解除) .

b) 小林市の対応 4

小林市中心部は新燃岳火口から北東に約 $12 \mathrm{~km} の$ 距離 にある．同市では1月27日の1回目の爆発的噴火後，広報 車て噴火に対する注意の呼びかけを行ったほか，「新燃 岳に関するお知らせ」を新聞折込として各戶に配布した . 1月31日には災害対策本部を設置し，緊急時に備え24時 間態勢て警戒にあたった．2月14日の爆発的噴火（11回 目) 時には, 同市内に $15 \mathrm{~cm}$ サイズの噴石が大量に降 り，自動車ガラスや屋根か割れたという報告が多数寄せ られ，兴の対応に追われた .

c) 高原町の対応 ${ }^{5}$

高原町では1月26日の噴火を受けて直ちに災害対策本 部を設置した 、翌27日には9世帯14人が避難所に自主避 難していたが，30日に宮崎地方気象台から県に「溶岩ド 一ムが大きくなり，火砕流発生のお光れがある」との情 報がもたらされ，連絡を受けた同町は513世帯1,158人に 避難勧告を発表した .この避難篗告は2月5日に一部解除 となるが , 全面解除されたのは2月15日であり，今回の 一連の噴火による避難生活としては最長のものであった . d) 霧島市の対応 9

霧島市では1月26日の噴火を受けて直ちに情報連絡体 制をとり，2度にわたる災害対策会議を開催した後，同 日18時に災害対策本部を設置し，気象庁発表の噴火警戒 レベル3に応じて県道の通行止めや登山規制等を行った . また，本庁と2箇所の総合支所に健康相談空口を設置し 住民からの相談に応じた . 同市はまた , 牧園町高千穂地 区と霧島地区神宮代の住民らに対しチラシや広報車によ る自主避難の呼びかけを行い，24時間体制て警戒に当つ た .さらに, 空振や火山灰の対応策や災害区域予想図 (ハザードマップ) ，自主避蜼先をまとめた広報誌 (号 外) や農作物の被害防止対策をまとめたチラシを配布す るなどし，住民の防災意識の啓発に努めた .

e) 国·県の対応 7,8$)$

爆発的噴火以降，国土交通大臣や防災担当相力相次い で両県入りし，被災状況を視察した．2月7日には，今後 の新燃岳の火山活動の活発化に備え, 火砕流や土石流発
表-4 県の対応策 (宮崎県)

\begin{tabular}{|c|c|}
\hline 項目 & 具体的対策 \\
\hline 県民への情報提供 & $\begin{array}{l}\text { ·県ホームページに「新燃岳の噴火に関する情報」を掲載 } \\
\text { •ラジオ, テレビによる広報 }\end{array}$ \\
\hline 健康管理 & 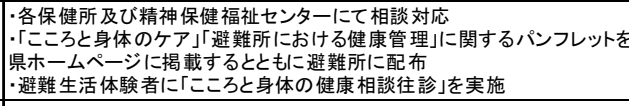 \\
\hline 福祉関係 & $\begin{array}{l}\text { ·土石流被害のおそれが高い地域の社会福祉施設に対し，避難体制の整 } \\
\text { 備に関する注意喚起 }\end{array}$ \\
\hline 環境調査 & $\begin{array}{l}\cdot \text { ·大気污染物質の測定 } \\
\cdot \text { 水質污濁物質の測定 }\end{array}$ \\
\hline 農林水産業 & 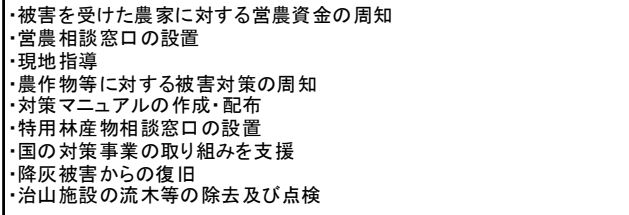 \\
\hline 道路関係 & $\begin{array}{l}\text { ·県管理道路の降灰除去作 業 } \\
\text { ·関係市町における降灰除去作業 }\end{array}$ \\
\hline 河川·砂防関係 & ·土石流や火山泥流発生の恐れのある河川に堆積している土砂を除去 \\
\hline 学校関係 & $\begin{array}{l}\text { ·臨床心理士を派遣し, 児童生徒の心のケアを実施 } \\
\text { 宮崎県棛資金の緊急採用制度の周知徹底 } \\
\text { ·生徒へのヘルメッ貨与 }\end{array}$ \\
\hline 警戒警備活動 & ·高原町を中心に地域の警戒警備を実施 \\
\hline 避難住民支援活動 & $\begin{array}{l}\cdot \text { ·女性警察官等で編成 } \\
\cdot \text { ·避難住民から䇾察安相談, 困りごと相談 }\end{array}$ \\
\hline 商工観光業 & 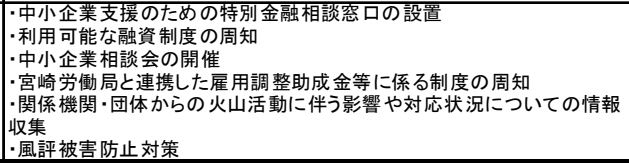 \\
\hline
\end{tabular}

表-5 県の対応策 (鹿児島県)

\begin{tabular}{|c|c|}
\hline $\begin{array}{c}\text { 項目 } \\
\end{array}$ & 具体的対策 \\
\hline 災害復旧·災害防止策 & 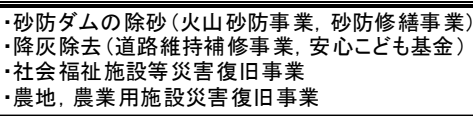 \\
\hline 生活支援 & $\begin{array}{l}\text { ·子どもの美育, 就学等への支援 } \\
\text { ·県税の免税措道 }\end{array}$ \\
\hline 農林業支援 & 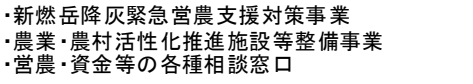 \\
\hline 中小企業への支援 & 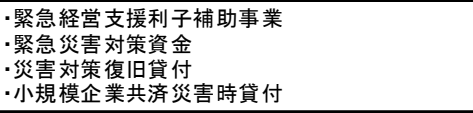 \\
\hline 観光·雇用·地域経済への支援 & 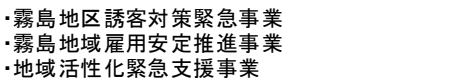 \\
\hline
\end{tabular}

生時の市町村の避䧼計画づくりを支援する政府チームが 宮崎県入りし，約1ヶ月の検討期間を経て，避難計画を 作成した .また国土交通省は, 既設砂防公么の除石, 遊 砂池の新設，監視カメラの設置などの応急対策を行った .

表4，表-5に，宮崎，鹿児島両県の対応策を光れ光れ 示す. 両県とも，災害復旧，生活再建，地域経済の支援 が大きな柱となっている.しかしながら，同地域は前年 に集中豪雨による土砂災害, 口蹄疫, 鳥インフルエンザ 感染に見舞われたばかりであり，火山噴火以前のこれら の復旧対策も同時に進めていく必要があるが, 予算的に も厳しい状況に置かれている。

\section{3. 火山噴火災害時の企業の対応と対策} 新燃岳噴火による企業活動への影響を把握することを 
表-6 ヒアリンク調査結果 (商工会議所・商工会)

\begin{tabular}{|c|c|c|c|}
\hline 項 目 / 団体名 & 都城商工会議所 & 山田町商工会 & 高原町商工会 \\
\hline 被害状況 & $\begin{array}{l}\text { ·降灰で出荷直前の農作物に被害あり } \\
\text { ·中小企業に多少なりとも被害あったが } \\
\text { 操 業停止に至ったところはない } \\
\text { ·飲食店ではキャンセルが相次いだ }\end{array}$ & $\begin{array}{l}\text { ·降灰で道路のセンターラインがわからない } \\
\text { スリップ事故の可能性も高まる } \\
\text { 影響が大きかったのは旅館業, ゴルフ場 } \\
\text { ·外出控えることにより, 来店者減少 } \\
\text { ·豆腐製造の機械が降灰被害 } \\
\cdot 3 / 27 \text { 時点で各商店の営業は } 80 \% \text { 回復 }\end{array}$ & $\begin{array}{l}\text { ·製材に灰が付き商品価值が下がった } \\
\text { ·精密機械の誤作動 } \\
\text { ·先行きが見えないことに対する不安と } \\
\text { ストレス }\end{array}$ \\
\hline $\begin{array}{l}\text { 対応と対策 } \\
\text { 今後の課題 }\end{array}$ & $\begin{array}{l}\text { 農業に対する支援は各種制度が充実 } \\
\text { しているが商エ業に対する支援は少ない }\end{array}$ & 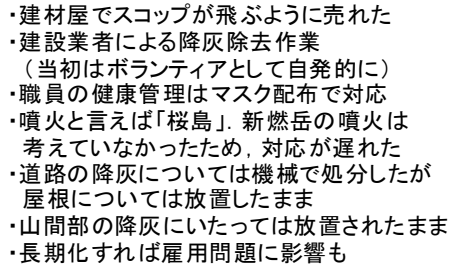 & $\begin{array}{l}\text { ·国や県に降灰除去支援を依頼 } \\
\text { ·自然と共生するかたちの農 羓を目指す } \\
\text { ·今の時代も「士農工商」, 工業と商業に } \\
\text { 対する支援が少ない }\end{array}$ \\
\hline 他の災害の影響 & $\begin{array}{l}\text { 【ロ蹄疫】 } \\
\text { ·対策は自助努カによるところが大きい } \\
\text { ·街の中心部にある大型店に民事再生法 } \\
\text { 適用 } \\
\text { ·宮崎ナンバーの車を入れないなどの風評 } \\
\text { 被害. 売り上げ咸少, キャンセルが } \\
\text { 相次いだ } \\
\text { 【東早本大震災】 } \\
\text { 顕著な影響はまだ見られない }\end{array}$ & $\begin{array}{l}\text { 【ロ蹄疫】 } \\
\text { 直接被害はなかったが, 宴会等の自 肃で } \\
\text { 飲食店や旅館が影響を受けた } \\
\text { 【東日本大震災】 } \\
\text { ·クラブチームのキャンセルが相次いだ } \\
\text { ·流通に顕著な影響はまだ見られない }\end{array}$ & $\begin{array}{l}\text { 【ロ蹄疫】 } \\
\text { 復興対策でプレミアム商品券配布 } \\
\text { 過去最高の売り上げを記録した } \\
\text { 【東日本大震災】 } \\
\text { 顕著な影響はまだ見られない }\end{array}$ \\
\hline
\end{tabular}

目的に，特に被害の大きかつた都城市及び高原町の商工 会議所 (商工会) や地元企業を対象にヒアリンク調査を 実施した . 調査日時は平成23年3月26日及び28日の2日間 である .なお，山田町商工会は都城市北西部の山田地区 にある .ここはもともと山田町という自治体であった . 2006年1月に都城市と合併したものの，商工会の統廃合 は進んでおらず今日に至っている .

今回の調査でのヒアリングの主な項目は, 各管轄域の 被害状況と当時の対応, 今後の対策や課題, 他の災害 (口蹄疫問題 , 鳥インフルエンザ, 東日本大震災) の影 響についてである。

表-6に商工会議所 (商工会) でのヒアリンク調査結果 を示す．また，表-7に都城市内にある企業に対するヒア リンク調査結果を示す．

被害状況についてみると，都城市街地では噴石被害は なく，降灰被害がほとんどであった . 細かい灰か建物や 精密機械内に入り，操業に支障か出た事業者もいたが， 完全停止に追い込まれるには至らなかった．

図-2に都城商工会議所に寄せられた業種別の相談内容 を示す. 全体で最も相談が多かったのは,「顧客減少」 についてで，次いで宿泊や宴会等の予約の「キャンセ ル」となっている.これらは観光客の訪問自肃, 地域住 民の外出を控えるといった消費者行動からくるものであ る.また，降灰除去や空振対策に追われ，少人数の事業 所では本来の業務に尃念できないといった声も多く聞 れた . 中小企業ほと現場の対応に追われ，人員力不足す る傾向にある，一企業での対応に任せるのではなく，商 工会議所 (商工会) か泞口となり会員の被災状況をすみ やかに把握し , 行政や災害ボランティアへ支援を仰ぐと いった体制づくりも必要になってくるであろう．

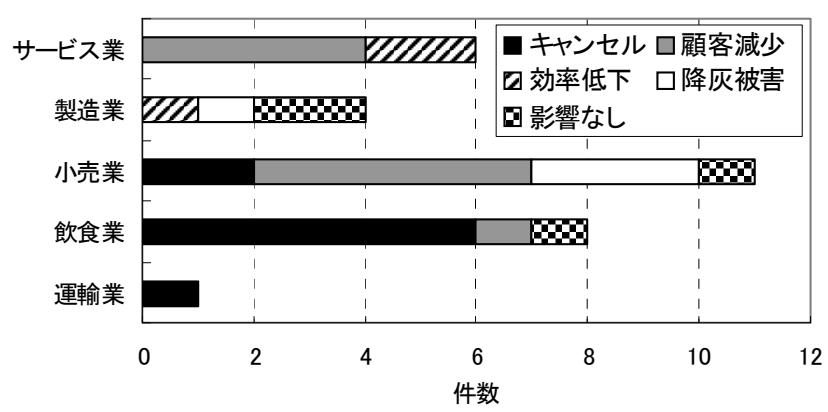

図-2 都㙇商工会議所への相談内容

今後の課題については, 商工業に対する融資制度の充 実を挙げる声が多かった .とりわけこの地域では農林業， 畜産業力盛んなところであり，光れらの産業の融資制度 に比へて商工業をサポートする体制が羊れをとっている と感じている事業者は少なくないようである．

影響を受けた他の災害としては, 直近の東日本大震災 や昨年の口蹄疫を取り上げる声が多かった . 東日本大震 災に関しては, 発生後2週間の時点であつたが, 部品調 達か困難になるなどの影響が見られるとの声が多く聞か れた .

\section{4. おわりに - 今後の課題 -}

霧島山噴火の災害危険性への認識及ひ防災対策につい ては, 活火山法や平成 9 年の宮崎県の報告等に準じて進 められてきたところであるが, 半世紀近くにわたり爆発 的噴火が見られなかったことから，具体的な対策の検討 は十分できていなかった . 今回の噴火活動により対策の 不備か露呈する結果となった .

都城市では灰除去の路面清掃車を持たないため，鹿児 
表-7 ヒアリンク調査結果 (都城市内の企業)

\begin{tabular}{|c|c|c|c|c|c|}
\hline \multicolumn{2}{|c|}{ 項 目/企業 } & T社 & $S$ 社 & M社 & K社 \\
\hline \multicolumn{2}{|c|}{ 会社規模 } & $\begin{array}{l}\text { 資本金 1億8000万円(全社) } \\
\text { 従業員 110名 }\end{array}$ & $\begin{array}{l}\text { 資本金 36億円(全社) } \\
\text { 従業員 約80名 }\end{array}$ & $\begin{array}{l}\text { 資本金 9億6000万円(全社) } \\
\text { 従業員 約500名 }\end{array}$ & $\begin{array}{l}\text { 資本金 2200万円(全社) } \\
\text { 従業員 約360名 }\end{array}$ \\
\hline \multicolumn{2}{|c|}{ 事業内容 } & $\begin{array}{l}\text { 各種機械のモーター, 競技用 } \\
\text { タイマーの製作 }\end{array}$ & $\begin{array}{l}\text { プラスチックフィルムコンデンサ等, } \\
\text { 電子部品の製作 }\end{array}$ & 牛乳，乳製品等の製造および販売 & 酒類の製造および販売 \\
\hline \multirow{4}{*}{ 被害状況 } & 建物被害 & 降灰あり & 敷地内全体で30tの降灰あり & 5cmほどの降灰あり & 敷地内, 屋根に降灰あり \\
\hline & 設備被害 & なし & 一部操 業停止(評価中) & $\begin{array}{l}\text { シャッター開閉部に灰が入り込む } \\
\text { (エ場内への影響なし })\end{array}$ & $\begin{array}{l}\text { エ場内には与圧をかけた空調を実施 } \\
\text { しているため, 灰の影響はなし }\end{array}$ \\
\hline & 操業への影響 & なし & なし(仕入先のほとんどが関西) & $\begin{array}{l}\text { ·製品パツケージへの灰の付着 } \\
\text { ·観光牧場の利用者減 }\end{array}$ & 製品パツケージへの灰の付着 \\
\hline & 従業員への影響 & 通勤等, 支障なし & $\begin{array}{l}\text { ·少し早い目の通勤で安全確保 } \\
\text { ·健康問題も発生せず }\end{array}$ & $\begin{array}{l}\text { ·マスク着用を奨励 } \\
\text { ·目の異常を訴える人がいる }\end{array}$ & $\begin{array}{l}\text { インフルエンザ対策で購入していた } \\
\text { マスクを活用 }\end{array}$ \\
\hline \multirow{3}{*}{ 対応と対策 } & 降灰除去 & $\begin{array}{l}\text { ·かわら業者に委託 } \\
\cdot \text { ·従業員も作業に従事 }\end{array}$ & $\begin{array}{l}\text { ·市役所に相談後, 業者委託 } \\
\text { ·手動スィーパー車を購入 }\end{array}$ & $\begin{array}{l}\text { ·業者委託(10tトラックで20台分) } \\
\text { ·従業員80人，2日間対応 }\end{array}$ & 従業員35名，1日対応 \\
\hline & 主な対応 & $\begin{array}{l}\text { 精密機械を取り扱っているので } \\
\text { 外気が入ってこないように } \\
\text { 出入りロを最小限にした }\end{array}$ & 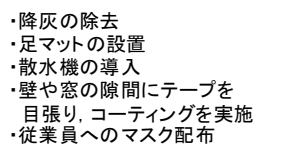 & $\begin{array}{l}\text { ·商品出荷時に着灰しないようフィルム } \\
\text { で棝包 } \\
\text { ·お見舞いとして取引先等からマスク, } \\
\text { 掃除機の提供を受ける }\end{array}$ & 製品パッケージへの灰はエアー除去 \\
\hline & 今後の対策 & $\begin{array}{l}\text { ·上記の対策を継続 } \\
\cdot \text { BCP策定のきっけとしたい }\end{array}$ & 搬入口前に前室を増設予定 & 特になし & イベント中止による影響の対策 \\
\hline \multicolumn{2}{|c|}{ 他の災害の影響 } & $\begin{array}{l}\text { 【東日本大震災】 } \\
\text { サプライエーン断絶 } \\
\text { 仕入先からの供給スップ }\end{array}$ & $\begin{array}{l}\text { 【東日本大震災】 } \\
\text { ·基盤の入手が困難 } \\
\text { ·禹北取先の製造拠点 } \\
\text { 変更を検討中 }\end{array}$ & $\begin{array}{l}\text { 【東日本大震災】 } \\
\text { ·自社ミネラルルカ増産し，支援物資 } \\
\text { として送付 } \\
\text { ·パッケージ，ペットボトル，キャップの } \\
\text { 確保が困難でこれ以上増産できず }\end{array}$ & $\begin{array}{l}\text { 【東日本大震災】 } \\
\text { ハハツケージ調達困難 } \\
\text { ·東北地方の配送センターが倒壞し, } \\
\text { 販売減 } \\
\text { ·イベント止による影響 }\end{array}$ \\
\hline
\end{tabular}

島市からの車輛と人員の提供を受けて道路に積もつた灰 の除去作業にあたつだ?. また，降灰専用の灰袋がく， 具体的な灰出しのルールや降灰対策についての情報力共 有されていなかったため，住民の混乱を招いた .これに ついは，垂水市などから桜島の降灰対策等の情報提供 を受け対応することで解決している。

また，今回の活動を受けて，当該自治体で初めて火砕 流発生時の緊急避難場所や災害力長期に及んた場合の避 難施設の選定 ，土石流を想定した避難計画に着手するこ ととなった . 今後 , この避難計画に基づき大規模噴火を

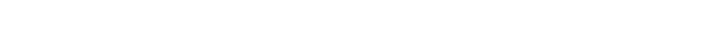

観光面では風評被害ともいえる宿泊の自肃，キャンセ ルか相次いだが, 同じ警戒レベル3の桜島でのダメージ は軽微であった .これについては, 報道の影響が大きい と考えられる . 事実 , 爆発的噴火のセンセーショナルな 映像に比へ , 光の後の施設の再開や観光客の戻りを伝え る報道はほとんどなされていない .

今回の噴火では, 弚の後の活動か収束する方向に向か ったものの，より事態か悪化した場合や影響が広範囲に 及んだ場合には，周辺自治体からの支援を受けることは
難しくなるものと予想される . 各自治体や企業が自らの 組織内で初動対応できる体制づくりと，火山災害を受け ない自治体とのより広域的な連携の確保力浗められる .

\section{参考文献}

1) 内閣府 : 霧島山 (新燃岳) の噴火による被害状況等 について (第 13 報)，10p., 2011.

2) 都城市：新燃岳火山噴火災害対策説明，視察団体等 提供資料 , 6p., 2011.

3) 都城市 : 霧島山の新燃岳約 300 年ぶりのマグマ噴火, 広報みやこのじょう2011年 3 月号，pp.2-7, 2011.

4) 小林市：新燃岳で爆発的噴火，広報こばやし 2011 年 3 月号, pp.2-5, 2011.

5) 高原町：新燃岳大噴火-鳴り響く地鳴りおびえる住民 一，広報たかはる 2011 年 3 月号，pp.8-16, 2011.

6) 霧島市：霧島山の新燃岳，189 年ぶ・りに大噴火, 広報 きりしま号外，8p., 2011.

7) 宮崎県 : 霧島山 (新燃岳) 噴火による被災及び対応 状況(平成 23 年 3 月 18 日現在)，8p，2011.

8) 鹿児島県 : 新燃岳噴火に係る当面の災害復旧・災害 防止対策及び各種支援策，14p. , 2011.

9) 南日本新聞公式サイト：http://373news.com/

(2011.7.22 受付)

\title{
DAMAGE AND CORRESPOBDENCE OF LOCAL GOVERNMENTS AND BUSINESS ESTABLISHMENTS FOR Mt. SHINMOE 2011 ERUPTIONS
}

\author{
Kohji UNO, Susumu NAKANO and Yoshio KASUBUCHI
}

On Jan. 27, 2011, Mt. Shinmoe in the Kirishima mountain range on the border between Kagoshima and Miyazaki Prefectures began erupting for the first time in 52 years. In this study, to clarify the damage and correspondence of local governments and business establishments for a series of volcanic hazards of Mt. Shinmoe in 2011, we conducted interview research and document investigation. For endless volcanic hazard, not only the serious and sustained effots of disaster-affected area, but also the broad-based supoorts from neighboring local governments and business establishments are required. 